\title{
Operations Research Approach to Enhancing Enterprise through Alliances: A case study of Mowe Town, Ogun State, Nigeria
}

\author{
J. A. O. Magbagbeola (Corresponding author) \\ Department of Actuarial Science \& Insurance \\ Joseph Ayo Babalola University \\ Osun state, Nigeria \\ E-mail: kunle.magbagbeola@gmail.com
}

O. M. Ayinde

Department of Business Administration

Joseph Ayo Babalola University

Osun State, Nigeria

E. A. Alo

Department of Business Administration

Joseph Ayo Babalola University

Osun State, Nigeria

A. I. Akosile

Department of Accounting

Joseph Ayo Babalola University

Osun State, Nigeria

E. O. Magbagbeola

Department of Business Administration

Lagos State University

Ojoo, Lagos State, Nigeria

Received: February 23, 2012

doi:10.5430/ijba.v3n3p2
Accepted: April 9, 2012 Published: May 15, 2012

URL: http://dx.doi.org/10.5430/ijba.v3n3p2

\begin{abstract}
Small firm sub-sector has the potential to reduce poverty and unemployment in Nigeria. However, in the face of global competition, market uncertainties and rapid technological changes, it is necessary to assist firms, particularly small enterprise to access information that can build their business competencies to create income and employment generation opportunities. Through in-depth recourse to existing theories and empirical literature on factors that explain firm growth, the study identifies business competencies, derived through inter-firm alliances, as determinants of enterprise performance. The study establishes that the size of the firm influences the choice of business association among manufacturing enterprises in Nigeria. It is further noted that the decision to join a business association is positively related to the ages of the entrepreneur and enterprise. The study recommends incentive mechanisms that encourage business associations among small enterprise.
\end{abstract}

Keywords: Alliance, Approach, Enterprise, Operations Research (O.R.) and Performance 


\section{Introduction}

The main economics challenges facing Nigeria today are unemployment and poverty. The Government of Nigeria and some other developing countries has put in place strategies to overcome these problems as articulated in many policy documents. According to Adegbite et al (2008), an Agricultural credit policy in Ogun State through this scheme was tailored towards efficiency in agricultural production using policy instrument of:

1. Revitalization of the institutional credit source through the establishment of the Ogun State Agricultural and Multipurpose Credit Agency (OSAMCA).

2. Using relatively low rate of interest compared to high rates charged by the commercial banks.

3. Giving allowances for less rigid conditions for borrowing decentralizing the agency through the establishment of zonal offices in addition to the State headquarters to bring the services nearer to intending beneficiaries

4. Creating innovations in credit delivery operations involving compulsory savings by potential beneficiaries or their group.

5. Providing reliable and sustainable source and supply of take-off grant and funds for the credit delivery.

Consequently it is necessary to assess the determinants of the demand for OSAMCA loan in Ogun state, Nigeria in meeting the credit needs of small and medium-scale fish farmers, describe the socio-economic characteristics of fish farmers, examine the existing patterns of supply of loans to fish farmers in the study area, determine the profit level of users of OSAMCA loans amongst fish farmers and identify the factors that influence the demand for Credit (OSAMCA LOANS) among fish farmers in Ogun state. With to do so is to have access to information relating to product design and development, markets and reduction of environmental uncertainties. Potentially alliances can facilitate information dissemination on innovations, markets band resources inputs, and also can enhance exchange by lowering transaction costs and foster group action. There is a dearth of research that identifies relational patterns across firms and the role these patterns play in enabling firms achieve better technical and managerial skills as well as information that reduces market uncertainties. This study explores the nature of alliances existing among small enterprises in Kenya and the potential of these inter-firm relationships in assisting firms to access information that can improve their performance and growth.

A lot of literature exists on the role alliances play in promoting enterprise development Hagedoorn et al (2003). The experience of small-scale wine growers in France and Italy reflects a typical case where cottage industries form alliance for distribution and marketing of their products. Similarly, the trade associations in the United States are useful avenues of gathering information through publications in addition to lobbying activities. The experiences of the Japanese automobile industry Fruin (1994), the industrial districts of North Italy. Schumitz (1995), and the public procurement-drive of small enterprises in California, United states. Saxenia (1994) suggest that institution al arrangements of firms' interrelationships enhance industrial growth in a country. These cited cases illustrate the role played by inter-firm networks in facilitating small-enterprises growth and the development of firm-focused assistance programmes. Furthermore, a more recent and striking example of cooperation is the airline industry alliances, e.g. the alliance between KLM and Kenya Airways. This study attempts to analyse the types of the alliances that exist among manufacturing firms in Kenya and the role of the alliances in promoting enterprise performance.

\section{Materials and Methods}

\subsection{Operation Definition}

In ordinary usage, the term alliances acquires slightly differ meanings depending on the context in which it is used. Any business exchange requires minimization of transaction problems of cooperation and coordination. This is possible if the necessary information is available. One postulate of a perfectly competitive market is permeable information flow. Thus, more can be accomplished at lower cost when resources are pooled, especially if organizations can complemented each other in terms of expertise and/or research facilities. An alliance is, therefore, a generic term covering many types of inter-firm cooperation over and above the normal market transactions Kirchhoff et al (2002). Such types of cooperation include long-term purchase agreements, business associations, franchising agreements, joint ventures an consortia. Whereas it may not be easy to completely disentangle inter-firm networks from alliance, Weber-Bleyle (2003) observed that networks differ from alliances in purpose, interdependence and criteria for membership. For instance, business associations and federations provide indirect service for their members but networks enable member to remain independent yet work directly together for mutual objectives. Similarly, whereas joint ventures normally pursue the objectives of two organizations through formation of separately managed venture, networks pursue organization 
objectives through coordination-based interactions of a number of individual firms that comprise an inter-organizational network.

The study area: Ogun state is located in the south-western part of Nigeria. It is bounded in the west by Republic of Benin and in the south by Lagos state, in the North both by Oyo and Osun states and in the East by Ondo state (Ogun state of Nigeria, 1998). Its lies within latitudes $6^{\circ} \mathrm{N}$ and $8^{\circ} \mathrm{N}$ and longitude $2.5^{\circ} \mathrm{E}$ and $5^{\circ} \mathrm{E}$. The state is approximately 19 percent, that is, 17,542 square kilometers of Nigeria's 923,219 square kilometers Land area with population of 3.3 million (Nation). Ogun state is a heterogenous state, inhabited predominantly by the Egba, Yewa, Ijebu, Remo, Awori and Egun who belong to the Yoruba ethnic group, the largest ethnic group in west African coast and one the largest and longest established ethnic groups on the Africa continent according to Olaoye et al(2007). Magbagbeola et al (2010) asserted that like in finance problems, the relationships between the variables are usually well defined, so that, for example, the way in which an increase in the proportion of a portfolio invested in a particular asset affects the mean and variance of the portfolio is clear. Thus the resulting OR model is a good representation of reality, particularly as the role of non-quantitative factors is often small. Finance problems also have the advantage that any solution produced by the analysis can probably be implemented, while in other areas there may be unspecified restrictions concerned with human behaviour and preferences that prevent the implementation of some solutions. Mortgage backed securities (MBS) are created by the securitisation of a pool of mortgages. For any specific mortgage, the borrower has the right to repay the loan early - the prepayment option, or may default on the payments of capital and interest. These risks feed through to the owners of MBS, in addition to the risks of fluctuations in the rate of interest payable on flexible rate mortgages Dey \& Chakraborty (2009). Thus MBS are hybrid securities, as they are variable interest rate securities with an early exercise option. Monte Carlo simulation can be used to generate interest rate paths for future years. OR techniques have also been used to help firms to determine the most appropriate method by which to raise capital from the financial markets to finance their activities. Tarim, S. A., \& Kingsman, B. G. (2006) put forward a chance constrained linear programming model to compute the values of the debt-equity ratio each period that maximize the value of the firm. Other studies have specified the choice between various types of funding as a linear goal programming problem according to Bertsimas, D., \& Thiele, A. (2006a) used linear programming to find the least cost financing decision for an investment project by a multi-national company.

$<$ Figure 1 about here $>$

\subsection{Approaches to Data Analysis}

This study analyses the nature of inter-firm alliances that exit among manufacturing in Nigeria and the factors that determine alliance formation among firms. To explore these aspects of the study, a combination of descriptive and analytical methods is applied to a stratified random sample of enterprises in Mowe town. The existence of an alliance is analyzed by classifying alliance membership across different firm sizes. To measure the size of the firm, a number of variables can be used that include employment level assets, sales and market value. There is a limitation to the extent to which these variables can distinguish firms in different size categories due to their correlation weakness. For instance, employment figures may reflect a firm's negative growth whereas market value and sales level could reflect a graduation of the firm from one size-category to another within a given period of time. As rightly pointed out by Paytas et al (2004), the choice of the measure of a firm's size is, in practice, governed by the data available. The number of employees and/or the size of the premise are criteria used by the Local government of Obafemi/Owode in classifying firms into different size categories. This study adopted the same criteria. Conventionally, there is no standard employment level that is used to categorise firms due to heterogeneity in structures and operation $\mathrm{s}$ of the firms. Researchers use different employment levels to categories firms, based on the type of analysis in question. For instance, Mukhtar \& Syeda-Masooda (2002) considers those firms with 1 to 9, 10 to 49 and at least 50 employees as small, medium and large firms respectively. Okafor (2000) regards small-scale firms to be those with less than fifty employees. The type of alliance formed gives a general picture of the usefulness of alliance in solving growth constraints. The extent to which the enterprise and entrepreneur characteristics influence the firm's choice of an alliance is explored by using a probit analysis.

\section{Results and Discussions}

A part form inter-firm networking, alliance are potential sources of information, membership to business alliances nay benefits firms through joint learning and collective sourcing of market and technological information. Firms may join various forms of alliances: business associations, joint venture and franchising agreements. Analysis of data from firms in Obafemi/Owode town shows that except for business associations, other forms of alliances are not prevalent among business firms. By categorizing firms in order of membership to business associations, our data show that only forty-one percent of the sampled firms have association membership (see Table 1.). 
$<$ Table 1 about here $>$

This pattern of alliances indicates that the size of the influences the choice of business association. Small and medium firms join associations that have potential to offer credit whereas large firms associate with organizations that can facilitate collective lobbying and access to information relating to the markets. As Table 1.0 shows, the decision to join business association is strongly related to the size of the enterprise. The proportion of firms who are members of business associations increases as we move from small, medium to large categories of firms. This is confirmed by the probit regression results (Table 2.0). Though statistically insignificant, the decision to join a business association is positively related to the ages of the entrepreneur and enterprise. Notably, the firm's sales have a significant positive effect on the probability of association, confirming that the size of the firm strongly influences the decision to join a business association. Monthly poverty lines per adult equivalent in rural and urban areas estimated at $\$ 1$ and $\$ 2$ respectively. According to Soludo (2008), Nigeria's per capita income is barely $\$ 1,000$; USA about $\$ 32,000$; South Africa over $\$ 5,300$. At current population growth rate, and if GDP grows at $13 \%$ p.a, it will be in 2033 that Nigeria achieves today's per capita income of SA. At current $6 \%$ growth, it will be in 2065 . Urbanization rate $5.3 \%$ as one of fastest in world, with urban youth unemployment at about 20\%---- This is a TIME BOMB waiting to explode!. It is expected that small enterprise sector will be the major source of new jobs Armington \& ACS (2002). The 1999 National Micro and small Enterprises Baseline survey estimates that there are about 1.3million small enterprises in Kenya with labour forces 2.4 million people. Small enterprises also generate as much as $14 \%$ of the country's Gross Domestics Product Mullei \& Bokei (1999). Research has shown that small enterprises growth can lead to rapid industrial transformation, as is the case of the south East Asian Economies as asserted by Kimuyu \& Omiti (2000).

An evaluation of the contribution of small enterprise to the Kenya economy should be analysed in the context of the economy's historical developments since the country's independence. Restrictive trade policy, the import substitution growth strategy and a government-regulated market in the first two decades after independence hampered economic growth in Kenya. In the early 1980's the government adopted the IMF/World Bank prescribed structural Adjustment Programmes (SAPs) that emphasized market deregulation, reduced government spending and tightened monetary controls. The rationale for SAPs was to stabilize the operational mechanism of the economy so as to create an impetus for economic growth. In spite of over 15 years' experimentation with SAPs the performance of Kenya economy in terms of Gross Domestics Product (GDP) growth is wanting. As Soludo (2008) observed, demand management policies have not generated adequate supply responses in Africa. Nigeria still relies on exporting few primary goods for it foreign exchange, exposing itself to vulnerability of commodity price shocks and unfavorable terms of trade. The infrastructure is inefficient and cost-sharing arrangements have played havoc on the health and education sub-sectors. This is noticed in most African countries and had been the bane of their development and growth. Furthermore, the high production costs make the few manufacturing exports uncompetitive in the world market.

It is within this historical setting that the government is shifting its policy towards revitalizing entrepreneurship at individual level (Federal Government of Nigeria, 2011). Given the slow growth of the industrial sector and the resurgences of the re-engineering policies in the modern firms to improve their competitiveness, a large pool of the unemployment will have to be absorbed in small business enterprises. Furthermore, the on-going trimming of the civil service will present new challenges to the small enterprise sub-sector as the employees who are declared redundant are expected to start small businesses for their livelihood.

An issue that arises from this scenario is whether small enterprises have the potential to reduce unemployment and alleviate poverty in Nigeria. Most small enterprises, particular in manufacturing, require some levels of managerial and technical skills Babai \& Dallery (2009). The high mortality rate of new businesses and slow enterprise growth suggest lack of achievement of objective and planning skills among the operators all small enterprises. An entrepreneurial culture is necessary for the creation and development of enterprises. Bollapragada, S., \& Morton, T. E. (1999) asserted that culture affects the performance of a firm since the existing entrepreneurial culture impacts on the transaction costs. Indeed, since an entrepreneurial culture is complex and specific, a firm (or an individual) enriched with it possesses a competitive advantage. Where an entrepreneurial culture is weak, enterprise performance and growth can be promoted through provision of business support services. Here, recourse is made to the women empowerment programme purportedly championed by various successive governments in the most African countries.

Nevertheless. It is not just the availability of business support service that will motivate entrepreneurs to learn the necessary skills and knowledge. As Axsater, S. (2007) puts it, there is more than just lack of finance, skills and demand that undermine enterprise growth among Africans. Assuming that better macroeconomic conditions and physical infrastructure are sufficient to spur industrial development, this position may be wrong since industrial progress requires a package of incentives, capabilities and institutions said Chen et al (2011). It is interesting to note that past efforts to 
ameliorate the macro environment in Nigeria have not necessarily resulted in higher entrepreneurial growth. In addition, the donor-supported business development services' organizations have not had significant impact on enterprise performance and growth in Nigeria and most developing African countries Okafor (2000). Unless a fundamental adjustment in growth dynamism of small enterprise occurs, the related problems of unemployment and poverty may persist for a long time in Nigeria. It is not just a lack of market, credit, support service or even competitiveness that hiders the growth of small enterprise; there seems to inherent weakness in information flow among Africa entrepreneurs. Even in situations where problem specific to African businesses have been reduced, non-African Nigeria businesspersons reflect better business performance and enterprise growth. In the face of global competition, rapid technological changes and complexity in input and output markets, small enterprise have to build their core competencies.

$<$ Table 2 about here $>$

One way long industrial experience, as captured by ages of entrepreneurs and the enterprise, may facilitate the entrepreneurs appreciation of the benefits derived from joining business association; in addition to making an informed choice of the right business association for the firm. But as firms grow, the probability of joining business associations increases to mitigate the growth constraints that results from the changing business environment. Taking into account the business association that large firms join, it is possible that the need for collective bargaining and easier access to market information becomes the central issues that large firms address through business associations.

\section{Conclusion and Recommendations}

\subsection{Access to Credit}

Formal financial institutions, particular commercial banks, attribute poor creditworthiness of small firms to high administrative costs of lending to small enterprises. The majority of owner-manager of small firms also basically lacks collateral for securing loans. Thus, unless the micro-finance institutions avail easy access to credit, many small enterprises' capital base will be restricted to self-finance, which is negligible in magnitude. However, findings from this study indicate that only few small enterprises approach micro-credit institutions and the government should create more awareness on existing micro-finance products so that small firms can be channeled through business associations. Small enterprises mainly join business associations that facilitate access to credit. The association's membership is a requirement by micro-credit organizations before approval of loan requests. A large number of small firms rarely keep records that accurately reflect the firms' operations, yet the micro-credit organisaions require this information for loan appraisal. Further, these finance institutions may not have cost-effective mechanisms of monitoring approved loans. Hence, many micro-credit institutions minimize costs and risks involved in availing credit by insisting that small firms form association s that become identifiable security. Individual firms have, therefore, no choice but to link up with other firms in case they want credit facilities. Existing mutual trust among firms is thus the binding factor that facilities alliance formation.

There are two issues that arise from this credit arrangement. First, since the credit access is demand-driven from a firm's perspective, small enterprises can benefit from business development services if they are incorporated in the credit programmes. Further, as Chang et al (2007) rightly puts it, credit organizations can act as a referral centre that links up firms to specialized training institutions. Second, the requirement of joining an association before loans are approved may be a disincentive to firms in choosing to seek credit from micro-finance institutions. Small firms may regard other similar firms as competitors and hence, any element of building mutual trust is eroded due to inter-firm rivalry. This aspect, perhaps, explain why $71.8 \%$ of small firms have not joined association $\mathrm{s}$ to seek credit from micro-finance institutions. There is need for existing micro-credit organizations to investigate the factors that inhibit small enterprises from accessing credit facilities offered. In addition, the micro-credit organizations should re-examine their loan appraisal requirements so that small firms are encourage to access credit. A well-structure business association may be a better referral of an entrepreneur seeking credit rather than a small grouping of people that lacks uniformity of purpose for its existence.

Finally, the government should enhance the efficiency of the micro-credit sub-sector by coordinating the activities of micro-finance institutions. It should also re-evaluate the banking act to accommodate the service offered by micro-credit institutions. The micro-credit institutions can be encouraged to form network arrangements that analyze the credit-seeking behaviour of practicing entrepreneurs.

\subsection{Alliances as a pool of Market Information}

Unlike small firms, large firms derive market information and collective bargaining from business associations, within the context of the market structure, facing the two categories of enterprises, the oligopoly nature of markets for large 
firms allows the formation of alliances through collusion. Small firms may, therefore, require external support to facilitate the formation of associations that increase access to market and collective bargaining. As scholars advocated, small firms' associations may lobby for public procurement arrangements that favour small enterprises. The government should provide incentives that encourage formation of associations that facilitate collective input purchases and better market avenues. Such incentives may include selective public procurement that favour small-firm business associations. Financial subsidies for associations' secretariat and availability of office spaces. Small enterprise associations are well placed to lobby for reserved allocation in public procurement, and also ensure that products from small-scale activities meet the quality standards prescribed in government quotations. Moreover, the transaction-costs involved if government departments were to be involved in exchange with individual small enterprises. Another crucial role the consortia of small enterprises can play is to act as economics agents in collecting export marketing information and disseminating it among associations' members. Individual entrepreneurs do not have the time and money to engage in the review of business reports and tracking down the market trends in international trade. Business associations would best serve these functions.

Based on the conclusions of this study the following recommendations are made to enhance small-scale enterprise perception, adoption of business enterprise strategies and expansion of business enterprise. To boost the morale of the small-scale business owners following must be done:

$\checkmark$ Government should make through strengthening of micro-finance and commercial banks soft loans available and affordable to the SMEs with low interest rate.

$\checkmark$ In its effort to reach the small-scale business owners in the state and maximize, marginal impact of the services rendered, there is a need for the government to give room for inter and intra-service placement in the zonal offices.

$\checkmark$ Innovative strategies that could reduce transaction cost of both the lender and borrowers and increase marginal returns on loans need adopted and encouraged.

$\checkmark$ Adequate infrastructure such as essential credit, good road network, rural electrification, which will enhance the adoption of innovation.

$\checkmark$ SME's owners should as a matter of urgency the need to form themselves into co-operative societies to make them have accessibility for the procurement of loan.

$\checkmark$ Research work should be carried out on the problems of SMEs growth and development in Nigeria.

$\checkmark$ The provision of training support programme in areas of SMEs advancement.

\section{References}

Adegbite, D. A., A. O. Oloruntoba and O. J. Olaoye (2008): Performance Assessment of Ogun State Agricultural and Multipurpose credit Agency (OSAMCA) in credit delivery and operation (2004-2006). Journal of Sustainable Development in Africa. Volume 10, No. 3, Pp. 127-153.

Armington C. and ACS Z. (2002) The determinants of regional variation in new firm formation, Regional Studies 36, 33-45. http://dx.doi.org/10.1080/00343400120099843

Axsater, S. (2007). Inventory control. Peking: Tsinghua University Press.

Babai, M. Z., \& Dallery, Y. (2009). Dynamic versus static control policies in single stage production-inventory systems. International Journal of Production Research, 47(2), 415-433. http://dx.doi.org/10.1080/00207540802426383

Bertsimas, D., \& Thiele, A. (2006a). Robust and data-driven optimization: Modern decision-making under uncertainty. INFORMS Tutorials on Operations Research (Chapter 4).

Bollapragada, S., \& Morton, T. E. (1999). A simple heuristic for computing nonstationary (s,S) policies. Operations Research, 47(4), 576-584. http://dx.doi.org/10.1287/opre.47.4.576

Chen, Y. W., Yang, J. B., Xu, D. L., Zhou, Z. J., \& Tang, D. W. (2011). Inference analysis and adaptive training for belief rule based systems. Expert Systems with Applications, 38(10), 12845-12860. http://dx.doi.org/10.1016/j.eswa.2011.04.077

Chang, R., Yang, J. B., \& Wang, H. W. (2007). An algorithm for training parameters in belief rule-bases based on the gradient and dichotomy methods. Systems Engineering (Special Issue, pp. 287-291, in Chinese).

Dey, O., \& Chakraborty, D. (2009). Fuzzy period review system with fuzzy random variable demand. European Journal of Operational Research, 198(1), 113-120. http://dx.doi.org/10.1016/j.ejor.2008.07.043 
Fruin, W.M. (1994) the Japanese Enterprise system: competitive strategies and cooperative structures. New York: oxford university press.

Hagedoorn, J; Kranenburg, H \& Osborn, R.N. (2003). "Joint Patenting Amongst Companies - Exploring the Effect of Inter-firm R\&D Partnering and Experience." Managerial and Decision Economics journal, 24: 71-84. DOI: 10.1002/mde.1078, John Wiley \& Sons Ltd.

Hart P.E. and Oulton, L (1996) "growth and size of Firms." - the Economics journal, Vol. 106, No. 438, pp. 1242-1252.

Kimuyu, P.K. \& Omiti J. (2000) "Institution Impediments to Access to Credit by Micro and Small Scale Enterprises in Kenya." IPAR Discussion paper. Nairobi.

Kirchhoff B., Armington C., Hasan I. and Newberts S. (2002) The influence of R\&D expenditures on new firm formation and growth [Online] Available: http://www.njit.edu/old/News/Releases/finalreport_10-02-02.pdf

Magbagbeola, J.A.O \& Adetoso, J.A (2011): Pricing Policy Models of Farm Produce" A Case Study in Practical Operations Research (O.R.). International Journal of Agirculture and Food Science, ISSN 2141-7156, Vol. 1, June 2011, pp. $171-184$.

Mullei, A. \& C. Bookei (1999) Micro and small Enterprises in Kenya: Agenda for improving the policy Framework. Nairobi: international center for Economic Growth.

Mukhtar, Syeda-Masooda, 2002, "Differences in Male and Female Management Characteristics: A Study of Owner-Manager Businesses," Small Business Economics, 18(4), 2002, 289-311. http://dx.doi.org/10.1023/A:1015235402335

Ness, W.L. (2002) A Linear Programming Approach to Financing the Multinational Corporation, Financial Management, vol. 1, no. 3, Winter, pp. 88-100. http://dx.doi.org/10.2307/3665376

Okafor, F.O. (2000). "Micro credit". An instrument for economic Growth and Balanced development", The Nigerian Banker, July- December, pp 38-45.

Olaoye, O. J; Adekoya, B. B; G. N. O. Ezeri; G. A. K. Omoyinmi and T. O, Ayansanwo (2007). Fish Hatchery Production Trends in Ogun State: 2001-2006. Journal of Field Aquatic Studies- Aquafield, Volume 3, pp. 29-40.

Paytas, J., Haakensen, A., \& Datla, A. (2004). Universities and the development of industry clusters. The Carnegie Mellon University Center for Economic Development. [Online] Available:http://www.smartpolicy.org/urole/university.html

Saxenia, A.L. (1994) Regional Advantage: Culture and Competition in Silicon Valley and Route 128. Cambridge, MA: Harvard University Press.

Schumtiz, H. (1995) 'Collective Efficiency: Growth path for small scale industry. The journal of Development studies, Vol.31, No.4, pp 529-566. http://dx.doi.org/10.1080/00220389508422377

Soludo, C.C. (2008). Making Finance Work, Convocation Lecture delivered at Federal University of Technology, Owerri, Imo State, Nigeria.

Tarim, S. A., \& Kingsman, B. G. (2006). Modelling and computing (Rn,Sn) policies for inventory systems with non-stationary stochastic demand. European Journal of Operational Research, 174(1), 581-599. http://dx.doi.org/10.1016/j.ejor.2005.01.053

Weber-Bleyle, M. (2003). The research park at UIUC: Impacting the business location decision making of enterprises. [Online] Available: http://ideas.repec.org/p/wiw/wiwneu/neurusp36.html. 
Table 1. Association membership by Enterprise Size

\begin{tabular}{|c|c|c|c|}
\hline \multirow{2}{*}{ Size of enterprise } & \multicolumn{3}{|l|}{ Belonging to an association } \\
\cline { 2 - 4 } & Yes & No & Total \\
\hline Small & $11(28.2)$ & $28(71.8)$ & 39 \\
Medium & $10(47.6)$ & $11(52.4)$ & 21 \\
Large & $8(72.7)$ & $3(27.3)$ & 11 \\
\hline Total & 29 & 42 & 71 \\
\hline
\end{tabular}

Pearson $\mathrm{chi}^{2}(2)=7.6053$, Note: figures in brackets are percentages $(\%)$

Sources: Computed from survey data, 2010

Table 2. Probit Estimates of Probability of Joining a Business Association

\begin{tabular}{|c|c|c|c|c|}
\hline Variable & Coefficient & Std. Error & $\mathrm{z}$ & $\mathrm{p}$ value \\
\hline Age of enterprise & 0.0326668 & 0.0175543 & 1.861 & 0.063 \\
\hline Number of employees & -0.170647 & 0.0107746 & -1.584 & 0.113 \\
\hline Age of entrepreneur & $9.42 \mathrm{e}-07$ & $4.68 \mathrm{e}-07$ & 2.012 & 0.044 \\
\hline No. of years of forma education & -0.0550667 & 0.0525635 & -1.048 & 0.295 \\
\hline Previous entrepreneurial experience & 0.0022137 & 0.0307573 & -0.072 & 0.943 \\
\hline Constant & -291216 & 0.9037279 & -1.429 & 0.153 \\
\hline
\end{tabular}

Number of observations $=$ Prob $>\mathrm{chi}^{2}=0.0002$

$\mathrm{Chi}^{2}(6)=26.78$ Pseudo $\mathrm{R}^{2}=0.2788$

Sources: Computed form survey data, 2010. 


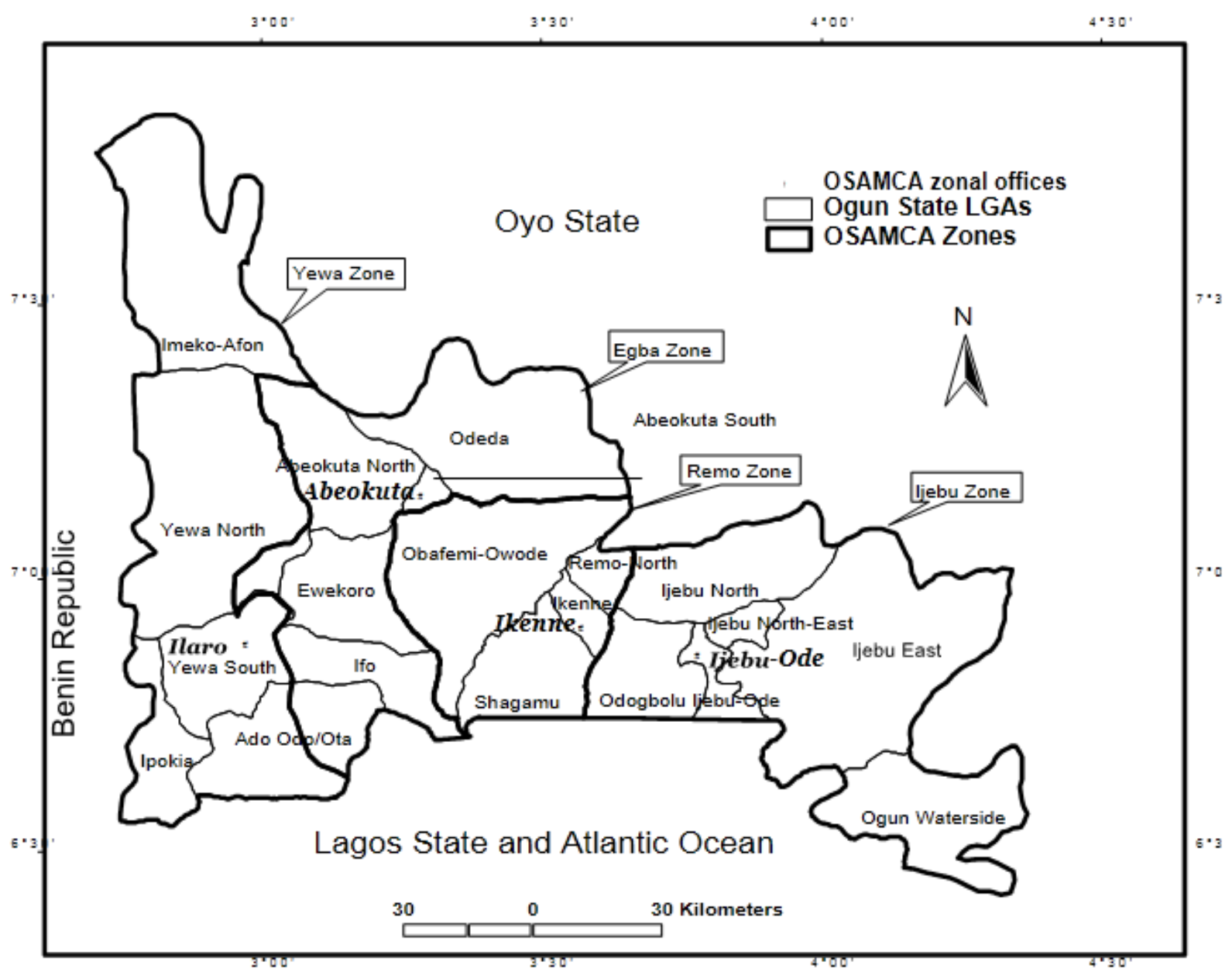

Figure 1. Map of Ogun state showing OSAMCA zones and study locations Source: Adegbite et al.(2008) 